\title{
Suomen illatiivi ja kognitiivisen kieliopin näkökulma taivutusmorfologiaan
}

\section{Johdanto}

Käsittelen artikkelissani Ronald W. Langackerin kognitiivisen kieliopin (Langacker 1987, 1991, 2000) käsitteiden ja termien mahdollista käyttöä suomen taivutusmorfologian kuvauksessa. Tarkastelen keskeisiä morfologisia teemoja, mm. allomorfien välisiä suhteita, valenssisuhteiden kuvausta ja taivutustyyppien asemaa taivutusmorfologian kuvauksessa. Artikkelin ulkopuolelle jää haaste, miten voisi kattavasti kuvata suomen morfologiaa kognitiivisen kieliopin teoreettiseen taustaan nojaten. Esimerkkinä toimivat useimmiten standardikielen illatiivi allomorfeineen, eli huomio kiinnittyy nominitaivutukseen.

Artikkeli pohjautuu laajempaan tutkimukseen (Hebedová 2016), jonka yhtenä tavoitteena on kognitiivisen kieliopin teoreettisten lähtökohtien soveltaminen suomen ja viron illatiivimuotojen kuvaukseen. Kognitiivinen kielitiede on ollut fennistiikassa viime vuosina aika keskeisessä asemassa, mutta sen soveltaminen suomen taivutusmorfologian kuvaukseen on tähän asti ollut melko vähäistä (morfologiaan liittyviä aiheita kognitiivisen kieliopin näkökulmasta käsittelee Leino 1999, 61-72, 91-100, 105). Toisaalta kaikki kognitiivisen kieliopin mukaiset näkökulmat eivät välttämättä ole suomen morfologian kuvauksessa uusia (kognitiivisen kieliopin ja suomalaisen morfologian perinteen samansuuntaisuudesta ks. Onikki-Rantajääskö 2012, 38-42). Samantapaisia ajatuksia ovat esittäneet esimerkiksi Heikki Paunonen (1976), Raimo Anttila (1974) ja Terho Itkonen (1976, 52-60), ja ne liittyvät kenttämorfologian perinteeseen (ks. Määttä 1998).

Esittelen ensin luvussa 1.1 illatiivin morfologiaa ja luvussa 1.2 joitakin kognitiivisen kieliopin keskeisiä käsitystapoja ja termejä, jotka liittyvät kategorisointisuhteisiin ja syntagmaattisiin suhteisiin. Luvussa 2 keskityn illatiivin allomorfeihin ja niiden välillä hahmotettaviin kategorisointisuhteisiin. Luvussa 3 keskityn syntagmaattisiin suhteisiin illatiiviesimerkkien avulla: illatiivin vartaloon, asymetriseen vartalon ja päätteen suhteeseen ja morfeemien hierarkiaan silloin, kun sijan päätettä edeltää monikon tunnus tai seuraa 
possessiivisuffiksi. Luvussa 4 puhutaan taivutustyypeistä ja monikon illatiivin päätteiden -siin ja -hin vaihtelun kuvauksesta. Luku 5 on yhteenvetoa. ${ }^{1}$

\subsection{Suomen illatiivi}

Illatiivin muodostus ansaitsee morfologian kuvauksissa genetiivin ja partitiivin ohella erityistä huomiota etenkin pääteallomorfien runsaan määrän takia. Illatiivin pääteallomorfit ovat - Vn, - hVn, -seen ja -siin (ISK \$93; Karlsson 1982, 290-291). Illatiivin pääteallomorfien jakauma näkyy taulukosta 1 .

Taulukko 1. Illatiivin pääteallomorfien jakauma

\begin{tabular}{|c|c|c|c|}
\hline & $\begin{array}{c}\text { vartalon lopussa lyhyt } \\
\text { vokaali }\end{array}$ & \multicolumn{2}{|c|}{ vartalon lopussa pitkä vokaaliaines } \\
\hline $\begin{array}{c}\text { illatiivin kolme } \\
\text { pääteallomorfia }\end{array}$ & $-\mathbf{V n}$ & $-\mathbf{h V n}$ & -seen/-siin \\
\hline yksikkö & - Vn $($ käte-en $)$ & $\begin{array}{c}\text {-hVn } \\
\text { suo-hon, tä-hän }) \\
\text { edellinen tavu } \\
\text { painollinen }\end{array}$ & $\begin{array}{c}\text {-seen }(\text { huonee-seen }) \\
\text { edellinen tavu } \\
\text { painoton }\end{array}$ \\
\hline monikko & -in & $\begin{array}{c}\text {-hin }(\text { asioi-hin }) \\
\text { jakauma riippuu } \\
\text { taivutustyypistä }\end{array}$ & $\begin{array}{c}\text {-siin }(\text { huonei-siin }) \\
\text { jakauma riippuu } \\
\text { taivutustyypistä }\end{array}$ \\
\hline
\end{tabular}

Illatiivin pääte liittyy vokaalivartaloon ja päätteiden jakauma ohjautuu vartalon loppuvokaaliston ja painosuhteiden mukaan. Yksikön pääte - Vn ja monikon pääte -in liittyvät lyhyeen vokaaliin päättyviin vartaloihin painosuhteista riippumatta (käte-en, kattilaan, asuntola-an, käsi-in, sinisi-in, hautajaisi-in, aavistamattomi-in). Näin morfeemirajan yli muodostuu pitkä vokaaliaines. Pääte $-h V n$ esiintyy pääpainollisen tavun jälkeen eli yksitavuisissa, pitkään vokaaliainekseen päättyvissä sanoissa (maahan, suohon, tiehen), eräissä pronomineissa (mihin, siihen, tähän) sekä pääpainottomien diftongien jälkeen, esim. tiistaihin, sunnuntaihin (Karlsson 1982, 291). Pääte -seen liittyy vartaloihin, joiden lopussa on painoton pitkä vokaali (huoneeseen, puolueeseen). Lainasanoissa tavataan vaihtelua $-h V n \sim$-seen, esimerkiksi suklaahan suklaaseen, esseehen esseeseen, jolloin päätteen valinta korreloi vierasperäisyyden asteen mukaan: sitaattilainoissa ja vieraskielisissä nimissä on tavallinen $-h V n$ (esim. Bordeaux’hon, Glasgow'hun), mukautuneissa lainoissa -seen, esimerkiksi suklaaseen, esseeseen (ISK \$ 93).

Monikon päätteiden - hin ja -siin jakauma ohjautuu muiden paradigmamuotojen mukaan (Itkonen 1959, 383, 385-388; Paunonen 1976, 101-102; Karlsson 1983, 292).

1 Kiitän artikkelin kahta arvioijaa kommenteista ja parannusehdotuksista ja samalla kaikkia, jotka ovat tarkistaneet artikkelin kieliasua. 
Joissakin nominityypeissä on mahdollinen ainoastaan pääte -hin (pankkeihin, asioihin), toisissa taas esiintyy yleensä pääte -siin (huoneisiin, rikkaisiin, tärkeisiin), vaikka -hin on myös mahdollinen, joskaan ei tavanomainen (ISK $\$ 94$; ks. myös Karlsson 1983, 292293). Jakauma voi perustua taivutustyyppeihin (ISK \$ 94). On myös mahdollista selittää jakaumaa kielen historialla: molemmat päätteet sopivat supistumisen kautta syntyneisiin vartaloihin, kun ei-supistuneisiin vartaloihin käy ainoastaan pääte -hin (LaaksonenLieko 1988, 31). Ero on siis siinä, päättyykö vartalo supistumadiftongiin tai alkuperäiseen diftongiin (Itkonen 1959, 385-386).

Edellä esitettyjen varianttien lisäksi tavataan muita päätevariantteja possessiivisuffiksin edellä, jossa asemassa kaikkien päätteiden loppu- $n$ katoaa, esim. huonee-see-si, talo-omme. Näin illatiivin pääteallomorfien määrä kaksinkertaistuu. Possessiivisuffiksin etisiä variantteja ei kuitenkaan ole syytä pitää samanvertaisina yllä esitettyjen pääteallomorfien kanssa, vaan nämä variantit on johdettava ensisijaisista $n$ :n sisältävistä varianteista (Karlsson $1983,32-33,291)$.

Suomi toisena kielenä -oppimateriaaleissa on tapana käsitellä yksikön illatiivin ja monikon illatiivin muodostamista erikseen (White 2001, 43-45, 53-55). Näin tehdään myös tässä artikkelissa, kun puhutaan kolmesta allomorfista yksikössä (-Vn, $-h V n$, -seen) ja kolmesta allomorfista monikossa (-in, -hin, -siin). Syynä on, että päätteiden jakaumasuhteet ovat osittain erilaisia yksikössä ja monikossa. Lisäksi monikon päätteet esiintyvät eri ympäristössä eli aina monikon tunnuksen jälkeisinä. Päätteiden $-h V n$ ja -seen valinnassa on S2-esityksissä primaarisena kriteerinä esitetty tavuluku: yksitavuisen vartalon jälkeen tulee käyttää - $h V n$ päätettä, useampitavuisen vartalon jälkeen päätettä -seen. Tätä sääntöä voivat kielenoppijan silmissä häiritä etenkin päivien nimet (maanantaihin, tiistaihin jne.), mutta niitä voi kuitenkin pitää poikkeuksina (White 2001, 45). Monikon illatiivin päätteiden -hin ja -siin valinta selitetään useimmiten taivutustyyppien avulla (White 2001, 54).

\subsection{Kielioppi yksikköjen varastona}

Tässä luvussa esittelen kolme relaatiota, joita pidetään kognitiivisessa kieliopissa perustavanlaatuisina: kategorisointi, symbolinen relaatio ja syntagmaattinen relaatio. Kiinnitän huomiota erityisesti kategorisointisuhteisiin ja vertaan kognitiivisen kieliopin lähestymistapaa suomen morfologian aiempiin kuvauksiin. Langackerin mukaan kielioppi on konventionaalisten kielen yksikköjen jäsentynyt varasto (Langacker 1987, 57). Kielen yksikkö on sellainen rakenne, jonka puhuja hallitsee sellaisenaan ja jota hänen ei tarvitse esimerkiksi koostaa osista eli jonka käyttö ei edellytä konstruktiivista ponnistelua (Leino 1989, 167; Leino 1999, 61). Kielen yksikkönä voi olla sananmuoto, kuten illatiivit kotiin tai sisään, jotka puhuja todennäköisesti hallitsee kokonaisuutena ${ }^{2}$. Lisäksi kielen yksikön status voi olla vakiintuneella yleistyksellä, esim. "vartalo + illatiivin pääte".

2 Kielen yksikön status voi olla selvempi tai vähemmän selvä, yksikön hallitseminen ja käyttö yksikkönä voi myös muuttua ajan mukaan. Kyseessä on asteittainen ulottuvuus. (Langacker 1987, 59-60.) 
Olennaista on se, millä tavoilla kielen yksikköjen varasto on jäsentynyt. Tämän jäsentymisen tunnistaminen ja kuvaus onkin kieliopin kuvauksen ydin. Jäsentymistä tarkastellaan erityisesti kolmessa ulottuvuudessa, joita ovat symbolinen relaatio, kategorisointisuhteet ja syntagmaattiset yhdistelmät (Langacker 1987, 73-75; Langacker 2000, 4-5). Symbolisen relaation kautta suhteutetaan symbolisen yksikön semanttinen napa, joka edustaa merkitystä, ja fonologinen napa, joka edustaa muotoa ${ }^{3}$.

Myös kieliopillinen morfeemi, kuten illatiivi, on symbolinen yksikkö, jolla on muoto ja merkitys. Yksiköt esiintyvät aina toisten yksikköjen kontekstissa eli erilaisissa syntagmaattisissa yhdistelmissä. Illatiivi esiintyy dependenttinä morfeemina pakollisesti ainakin yhteydessä nominivartaloon, ja ilman nominivartalon huomioon ottamista ei voi käsittää illatiivin muotoa eikä merkitystä; silti laajempikin (useamman sananmuodon tai lauseen) konteksti on usein olennainen. Tällöin on kyse syntagmaattisesta suhteesta. Tarkastelen syntagmaattisia suhteita jäljempänä luvussa 3 .

Kategorisointisuhteissa puhutaan standardirakenteesta ja tavoiterakenteesta; ensimmäiseen verrattuna arvioidaan toista. Kategorisointisuhteesta on kyse silloin, kun muotoja, kuten taloon, kotiin, seinään yms., yhdistää skeema ...Vn (jossa vartalo jää skemaattiseksi ja skemaattinen on myös päätteen vokaali). Tällainen skeema, [ILL.SG/...Vn] ${ }^{4}$, on kielen skemaattinen yksikkö. Toisiaan muistuttavien esimerkkien pohjalta (taloon, kotiin, seinään, kattilaan, asuntoon, matematiikkaan) puhuja tekee yleistyksen, joka jättää avoimeksi esimerkiksi sen, mikä vokaali pitenee tai kuinka monesta tavusta vartalo koostuu. Skeema tarjoaa mahdollisuuden kategorisoida muutkin muodot, kun niitä verrataan tähän skeemaan (Langacker 2000, 5). Osoitus tällaisesta kategorisoinnista on esimerkiksi se, miten kieleen tulevat uudet lekseemit mukautuvat olemassa olevien lekseemien taivutuksen malleihin. Kyseistä skeemaa [ILL.SG/...Vn] voidaan käyttää vaikkapa sellaisissa muodoissa, kuin Nõlvaan, Varénaan, Mikulčiceen, Helmstadtiin, jotka oletettavasti eivät itse ole kieleen vakiintuneita yksikköjä - eivät ainakaan samassa määrin kuin illatiivit

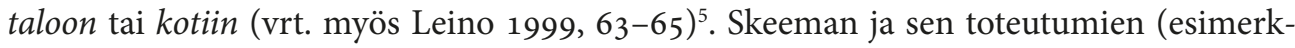
kien) välillä on siis kategorisointisuhde.

Yksikön statuksen voi olettaa olevan monella skeemalla, joiden skemaattisuuden taso vaihtelee (esim. [ILL.PL/...ihin] tai [ILL.SG/...VVseen]). Mikäli on tarpeen muodostaa uusi muoto, jota ei hallita sellaisenaan, sitä ei tarvitse koostaa aivan perusosista

3 Symbolinen yksikkö on sellainen kokonaisuudessaan hallittu rakenne, jolla on semanttinen ja fonologinen napa (muoto ja merkitys). Yksinkertaisin symbolinen yksikkö on morfeemi. Kaikki kielen yksiköt eivät ole symbolisia, esimerkiksi foneemit tai tavut ovat yksikköjä, mutta eivät symbolisia. (Langacker 1987, 58.)

4 Hakasulkeita käytetään osoittamaan yksikön statusta, vinoviiva merkitsee symbolista relaatiota sen vasemmalle ja oikealle puolelle merkityn välillä.

5 Jokaisen illatiivimuodon (tai jokaisen taivutusmuodon) varastointi yksikkönä ei ole todennäköistä, ja samalla on syytä olettaa, että frekventtejä muotoja kuten kotiin tai sisään ei tarvitse koostaa osista. Konreettisen muodon tapauksessa olisi kuitenkin vaikeaa sanoa, onko se varmasti olemassa varastossa valmiina yksikkönä vai ei, vaan ääripäiden (varastointi yksikkönä ja muodostaminen nojautuen skeemaan) väliin oletetaan jäävän jatkumo. 
(morfeemeista), koska on mahdollista turvautua tämäntyyppisiin osittain skemaattisiin yksiköihin. Puhujat voivat myös käyttää saman muodon aikaansaamiseksi eri resursseja: esimerkiksi monikon illatiivi kirjoihin voi olla jossain määrin vakiintunut yksiköksi sellaisenaan - [ILL.PL/kirjoihin] -, mutta samalla se on skemaattisen yksikön [ILL.PL/...ihin] toteutuma.

Kognitiivisen kieliopin mukaiseen käsitykseen kategorisoinnista kuuluvat olennaisesti myös ns. täyden ja osittaisen sanktioinnin käsitteet (Langacker 1987, 66-73). Skeeman ja sen toteutuman välillä on täysi sanktiointi silloin, kun skeeman ja toteutuman välillä ei ole ristiriitaa (esim. muodot Nõlvaan tai Helmstadtiin ovat skeeman [ILL.SG/...Vn] hyviä esimerkkejä). Osittaisessa sanktioinnissa kategorisoitu muoto poikkeaa joissakin yksityiskohdissa siitä rakenteesta (esim. skemaattisesta yksiköstä), johon sitä verrataan. Kategorisoitu muoto on siten skeemaan nähden laajentuma (extension). Täyden ja osittaisen sanktioinnin välillä ei kuitenkaan oleteta olevan jyrkkää rajaa, vaan niitä ajatellaan pikemminkin jatkumona. (Langacker 1987, 65-73, 369-386; vrt. myös Leino 1999, 67.)

Esimerkiksi vierassanat osoittavat, että jokin rajoitus olemassa olevien illatiiviskeemojen käytössä on mahdollista ylittää. Jos esimerkiksi päätteen - $h V n$ käyttö pääpainollisen tavun jälkeen (maahan, yöhön) katsotaan tyypilliseksi, niin sen käyttö yhdyssanoissa (satumaahan, kyynärpäähän) ${ }^{6}$ ja vierasperäisissä sanoissa ja nimissä (ateljeehen, kabaree$h^{7} n^{7}$, Glasgow'hun) voidaan tulkita laajentumaksi tai pikemmin laajentumaketjuksi, jossa yhdyssanojen tarjoama malli mahdollistaa mallin laajentumisen vierasperäisiin sanoihin.

Vierasperäisten sanojen variaatiota yksikön illatiivissa tyyppiä - $h V n \sim-$ seen (esim. ateljeehen ateljeeseen) voi siis kuvata niin, että ne voidaan sanktioida kahdella eri skeemalla, [ILL.SG/...seen] ja [ILL.SG/...hVn]. Skeemaa [ILL.SG/...hVn] käytetään pääpainottoman tavun jälkeisenä edellä mainitun laajentumaketjun ansiosta. Skeemaa [ILL.SG/...seen] taas voidaan käyttää, koska päätettä -seen käytetään kotoperäisillä pitkään vokaaliin loppuvilla vartaloilla (esim. käsitteeseen), joihin vierasperäiset sanat samastuvat. Onkin todettu, että pääte -seen on tavallisempi mukautuneissa vierassanoissa (ISK \ 93).

Vaikka osittainen sanktio on kognitiivisen kieliopin termi ja kognitiivisen kieliopin tapa kuvailla kielen joustavuutta, ei ajatus vaikutuksista, jotka eri suunnilta motivoivat eri morfologisia muotoja ja mahdollisesti synnyttävät vaihtelua, ole tietenkään uusi. Monikon illatiivin päätteiden -siin ja -hin vaihtelussa (esim. vapaisiin vapaihin) on Terho Itkosen $(1959,385)$ mukaan molemmilla varianteilla oma motivaatio taivutussysteemissä: päätteen siin käyttöä tukee päätteen -seen käyttö illatiivin yksikössä (jolloin saavutetaan vastaavuus seen : -siin), ja päätteen -hin käytön puolesta puhuu taas se, että se esiintyy muiden sanatyyppien monikon illatiivissa diftongin jälkeisenä, mikä tuottaisi kaikkiin

6 Tapauksesta Thaimaaseen pro Thaimaahan tulee ilmi, että myös hahmottuminen yhdyssanaksi voi olla tärkeä päätteiden $-h V n$ ja -seen jakaumassa. Joensuu tai kyynärpää olisi sen mukaan hahmotettu yhdyssanoiksi, tai toinen selitys voisi olla, että niiden tapauksessa on illatiivimuoto jo siinä määrin vakiintunut, ettei yhdyssanan rakenteen hahmottamisen haaalistuminen enää vaikuta siihen.

7 Kummankin illatiivimuodon (ateljeehen, kabareehen) käyttöä havaitaan Kielipankin lehtiteksteissä (http://www.csc.fi/tutkimus/alat/kielitiede). 
sanatyyppeihin yhtenäisen monikon illatiivin mutta kadottaisi yksikön ja monikon illatiivin vastaavuuden. Ensimmäiseksi mainittu vaihtoehto (vastaavuus -seen : -siin) on Itkosen mukaan selvästi voimakkaampi tendenssi. Sama päätelmä tulee ilmi myös myöhäisemmistä tutkimuksista (vrt. Karlsson 1982, 292-293; ISK \$ 94; Virkkala 2013, 23-25, 75-81). Heikki Paunosen (1976) suomen taivutusjärjestelmän kuvauksessa koko systeemiä luonnehtivat erisuuntaiset ja erivahvuiset vaikutusyhteydet ja taivutussysteemi on näin tällaisten yhteyksien dynaaminen kenttä.

Kognitiivisen kieliopin mukaisessa kuvauksessa täytyy myös korostaa käyttöpohjaisen (usage-based) lähestymistavan keskeisyyttä (Langacker 2000, 1-3). Kuten edellä sanotusta jo käy ilmi, skeemaattisia kielen yksikköjä (esim. [ILL.SG/...Vn]) saadaan esiintyvien muotojen (esim. ILL.SG/taloon, ILL.SG/kaikkeen, ILL.SG/puutarhaan) pohjalta, eli analyysin etenemistapa on alhaalta ylös. Teoreettinen malli ei siis pyri ekonomisuuteen, jossa muotoja johdettaisiin yleisiin periaatteisiin nojautuen, vaan konkreettisemmatkin muodot kaikenlainen idiosynkraattisuus mukaan lukien ovat huomion keskipisteessä (Langacker 2000, 1). Samaa suhtautumista morfologiaan ja suomen nominitaivutuksen kuvaukseen on Paunosella $(1976,83)$, jonka mukaan kuvauksessa täytyy antaa etusija abstraktimpien yksikköjen (kuten morfeemien) sijasta konkreettisemmalle tasolle (kuten allomorfeihin) ja kuvauksen täytyy myös osoittaa näiden relevanttien morfologisten yksikköjen väliset yhteydet. Paunosen kuvauksessa ovat näissä yhteyksissä keskeisiä assosiatiiviset suhteet eli analogiaan pohjautuva pyrkimys yhtäläisyyteen (mt. 84-85). Suomen nominitaivutuksen järjestelmä on selitettävissä näiden vaikutusten dynamiikan kautta, jonka perusteella järjestelmää luonnehditaan suhdeverkoksi, "dynaamiseksi kentäksi, jossa eri elementtien suhteita säätelevät erisuuntaiset ja erivahvuiset yhteydet" (mt. 85). Myös kognitiivisen kieliopin kuvaamaa yleistystä skeemoihin ja kategorisointia, joka tapahtuu vertailemalla taivutusmuotoja tällaisiin skeemoihin, on mahdollista pitää analogiaan pohjautuvana, vaikkei analogian termiä usein mainita (vrt. Langacker 1987, 447; Onikki-Rantajääskö 2012, 34-37).

\section{Illativin morfeemi}

Seuraavaksi keskityn siihen, millä tavalla yllä esitettyjen kategorisointitapojen käsitystä voi soveltaa illatiivin kuvaukseen morfeemina. Ensin vertailen sijan polysemian ja allomorfian kuvauksia ja sitten kiinnitän huomioni illatiivin yksikön ja monikon päätteiden symmetrisyyteen. Sijan merkitystä pidetään kognitiivisessa lingvistiikassa yhtenäisenä (koherenttina) kategoriana, jonka alapredikaatit kytkeytyvät toisiinsa erilaisten kategorisointisuhteiden kautta ja muodostavat näin useimmiten varsin laajan polyseemisen verkon. Tämä polyseeminen verkko kokonaisuudessaan vastaa sijan (tai muun kieliopillisen tai leksikaalisen morfeemin) merkitystä (Langacker 1991, 379, 398-403; Janda 2013; vrt. myös Leino et al. 1990, 12-43). Polyseemisella verkolla todetaan usein olevan jonkinlainen keskus, josta alkaen kategoriaa yleisesti kuvataan. Paikallissijojen tapauksessa pidetään yleensä prototyyppinä kolmiulotteisessa ulottuvuudessa ilmaistua suhdetta (vrt. 
esim. astu sisään, hän tuli jo kotiin). Perusteena on tällaisen suhteen kognitiivinen primaarisuus ja helppous (Onikki 1994, 75-77; Vainik 1995, 46-48, 142). Sellaisia suhteita kuin osa-kokonaisuus-suhde (hänet luetaan modernisteihin) tai kausaalinen suhde (kuolla nälkään) pidetään vähemmän prototyyppisinä. Sijan merkityksen kuvaus on koko laajan polyseemisen verkon ja siinä olevien kytkösten kuvausta (illatiivin merkityksen kuvaus kognitiivisen kieliopin mukaan ks. Uusitalo 1996).

Kuten Leino (1999, 129-130) toteaa, on kuitenkin vaikeaa kuvitella skeemaa, joka yhdistäisi kaikkia illatiivin päätteitä ja olisi samalla kohtuullisen informatiivinen. Onko päätteiden välillä yhteyksiä samalla tavalla kuin illatiivin merkitysten välillä on? Yleensähän katsotaan, että allomorfeja (tässä tapauksessa ensisijaisesti - $h V n,-V n$, -seen, -hin, -in, -siin) yhdistää viime kädessä se, että ne ovat yhden symbolisen yksikön ilmentymiä. On silti mahdollista ajatella Langackerin $(1987,387-388)$ tapaan hyvin yleistä skeemaa, joka olisi yhteinen kaikille illatiivimuodoille, ja fonologisella puolella maksimaalisen skemaattinen, eli [ILL/...]. Kolmella pisteellä kuvattaisiin siis mitä tahansa foneemijonoa, joka olisi suomessa mahdollinen ja joka voisi olla sananmuoto. Toisaalta suomen illatiivi on kuitenkin spesifimpi, koska fonologinen napa koostuu aina vartalosta ja siihen liittyvästä suffiksista. Voisi ajatella, että kaikkia illatiivin variantteja yhdistää lopussa oleva foneemi $n$, mutta koska $n$ kuitenkin katoaa possessiivisuffiksin edeltä, ei tämäkään fonologinen piirre yhdistä kaikkia illatiivimuotoja. Kaikille illatiivin muodoille tuntuu olevan yhteistä ainakin se, että vartaloon liitetty suffiksi sisältää vokaalin, mutta se taas on suomen taivutusmorfologiassa hyvin yleinen fonologinen piirre.

Kuten edellä on esitetty, on illatiivin muotojen pohjalta mahdollista tehdä yleistyksiä skeemoihin tai laajennuksia. Yleistäminen skeemoihin, esim. [ILL.SG/...Vn], [ILL.SG/ ...hVn], [ILL.SG/...seen], [ILL.PL/...hin], [ILL.PL/...in], [ILL.PL/...siin], onkin perinteistä ja kieliopeissa tavallista ${ }^{8}$. Tällaisia skeemoja voidaan verrata myös ISK:n mainitsemiin taivutusmuototyyppeihin - taivutussysteemissä esiintyviin muotteihin (ISK \$ 148) eli esimerkiksi $\square$ seen, jossa skemaattisen vartalon vastineena on muotin muuttujaosa (eli $\square$ ) ja skeeman spesifisen osan (yleensä päätteen) vastineena on taas muotin vakio-osa.

Konkreettisten illatiivimuotojen ohella nousee siis illatiivin muodon kuvauksessa keskeiseen asemaan kuusi mainittua välitason skeemaa, ja niiden rinnalla voi puhua myös niitä yhdistävästä ylemmän tason skeemasta. Eri tasoilla tehtävä yleistys ei ole morfologian kirjoituksessa uutta - välitason skeemat vastaavat allomorfien tasoa, ylemmän tason skeemalle on vastaava termi morfeemi (vrt. Langcker 1987, 388-396). Karlsson (1982, 33) erittelee vielä kvasimorfeemien tason, jonka hän sijoittaa allomorfien ja morfeemin tason väliin - illatiivin kvasimorfeemit ovat esimerkiksi $-h V n$ ja $-V n$ ja niiden allomorfit sitten -han, -hän, -hin, -hen jne. ja -an, än, -in, -en jne. Tilanne muistuttaa jossain määrin polyseemisen merkityksen kuvausta: mahdollinen yleisin skeema (muoto, jossa vartaloon on liitetty illatiivin pääte, sekä merkitys 'illatiivi') on niin skemaattinen, ettei se kerro paljon.

8 Skeemat [ILL.SG/...Vn] ja [ILL.PL/...in] sekä [ILL.SG/...hVn] ja [ILL.PL/...hin] on tapana yhdistää skeemoiksi [ILL/...Vn] ja [ILL/...hVn] (vrt. ISK \$ 93; Karlsson 1982, 290-291). 
Luonnehtimisen kannalta hyödyllisempiä ovat konkreettisemmat skeemat: fonologisella puolella kuusi mainittua skeemaa, semanttisella puolella esimerkiksi spatiaalista tai osakokonaisuus-suhdetta ilmaisevat skeemat. Toisaalta morfeemin käsite perustuu juuri mainittuun yleistettyyn skeemaan [ILL/...].

Allomorfien kesken voi havaita muitakin kategorisointisuhteita. Monikon päätteitä - hin, -in ja -siin voi pitää jonkinlaisina laajentumina yksikön illatiivin allomorfeista, mahdollisesti jossain määrin historiallisestikin (Rapola 1965, 261), mutta tällainen käsitys on mahdollinen myös historiallista kehitystä huomioon ottamatta. Monikon päätteissä on päätteen vokaalina vaihtelematon $i$, jota voi pitää jonkinlaisena "monikon vokaalina", koska se on monikon tunnuksen vokaali, joka toistuu illatiivin päätteen vokalismissa. Suhdetta yksikön variantteihin voi kuvailla siten, että päätteen vokaali vaihtuu monikossa $i$ :ksi, oli yksikössä mikä tahansa vokaali. Tällainen päätteen vokaalin vaihtelu monikon tunnuksen mukaiseksi ei ole suomen sijasysteemissä muuten tavallinen. Voidaan katsoa, että päätteen vokaali toimii muodon monikollisuuden varmistuksena tai tukena, kuten tapauksissa kauniiseen : kauniisiin. Monikon illatiivin päätteillä olisi sitten yhteinen skeema "päätteen vokaalina on i". Samalla monikon päätteitä voi pitää yksikön päätteen laajentumina: - $h V n$ toimii pohjana - $h i n$ päätteelle ja - Vn puolestaan -in päätteelle, ja sama suhde on päätteiden -seen ja -siin välillä. Siitä, että kyse on laajentumasta, jonka pohjana on yksikön pääte, kielii päätteen -siin pitkä vokaali, jonka mallina on päätteen -seen pitkä vokaali. Pääte -siin on sitten illatiivimuotojen skemaattisessa verkossa motivoitu kahdesta suunnasta: toisaalta se on skeeman "monikon illatiivissa päätteen vokaalina on i" toteutuma, toisaalta se on päätteen -seen laajentuma (kuva 1).

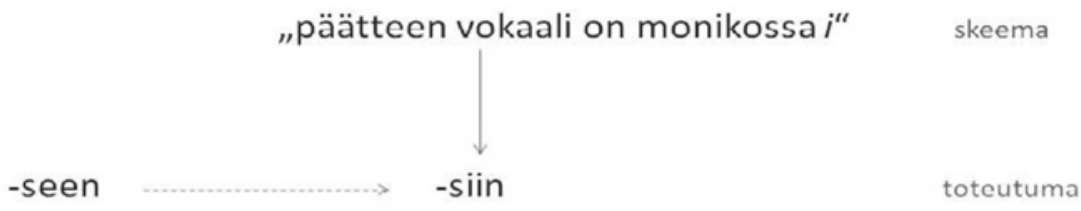

standardirakenne tavoiterakenne

Kuva 1. Monikon illatiivin päätteen -siin motivaatio kahdesta suunnasta

Pystyakselilla on kuvattu skeema-toteutuma-suhde eli kategorisointi skeeman avulla, vaaka-akselilla kategorisointi allomorfien samahahmoisuuden avulla. Ensimmäisessä

9 Samantyyppistä vokaalin vaihtelua tavataan kuitenkin possessiivisuffiksin - Vn tapauksessa tai verbitaivutuksessa esim. passiivin imperfektissä, konditionaalissa tai potentiaalissa (vrt. vaimolleen, sanotaan : sanottiin : sanottaisiin : sanottaneen), jolloin pääte $(-V n)$ kopioi edeltävän morfeemin (sijan, imperfektin, konditionaalin, potentiaalin) vokaalin. Sijapäätteistä tavataan vastaavaa ilmiötä vain monikon illatiivissa. 
suhteessa on kyse täydestä sanktioinnista, jälkimmäisessa osittaisesta (siksi katkoviiva) (ks. Langacker 1987, 68-70, 371-372; ks. myös Leino 1999, 65-68). Samalla tavoin voisi pitää kahdesta suunnasta motivoituneina myös päätteitä -in ja -hin. Näin voidaan kuvata myös illatiivin päätteiden symmetrisyys yksikössä ja monikossa siitä huolimatta, että ne eivät aina toimi toistensa variantteina samoissa konteksteissa: sama vartalo ei aina saa yksikössä ja monikossa vastaavaa päätettä, vrt. esim. taloon : taloihin, tärkeään : tärkeisiin, vaikka toisilla vartaloilla jakauma on symmetrinen, vrt. suohon : soihin, huoneeseen : huoneisiin.

\section{Syntagmaattisia suhteita}

\subsection{Illatiivin vartalo}

Illatiivin muotojen analyysissa ei tarvitse ja ehkä ei pitäisikään rajoittaa huomiota ainoastaan päätteisiin, vaan myös vartalon variantin voi katsoa osallistuvan konkreettisen muodon ilmaisemiseen. Illatiivin tapauksessahan on niin, että illatiivin pääte lähes poikkeuksetta liittyy astevaihtelullisten sanojen vahvaan vartaloon. Poikkeuksena ovat monitavuiset $a$ - ja $O$-vartalot, joiden monikon illatiiveissa voi esiintyä sekä vahva että heikko aste, esimerkiksi yksiköihin yksikköihin, poliitikoihin poliitikkoihin, navetoihin navettoihin (Itkonen 1957; Karlsson 1982, 335; ISK $\$ 43$ ). ISK:n mukaan ( $\$ 94$ ) on kolmitavuisilla $-k k A$ ja $-k k O$ loppuisilla sanoilla useimmiten heikkoasteinen illatiivi (mansikoihin, yksiköihin, kännyköihin), nelitavuisilla vahva-asteinen illatiivi (poliitikkoihin), ja vaihtelua tavataan myös muilla sanoilla (navetoihin $\sim$ navettoihin, marketteihin $\sim$ marketeihin). Saadakseni laajempaa tietoja tämäntyyppisten sanojen vahvan tai heikon vartalon esiintymisestä monikon illatiivissa, keräsin niiden esiintymistapauksia korpuksen (https://korp.csc.fi) Internet-keskusteluaineistoja-osasta ${ }^{10}$ (2 821358728 sanetta).

Taulukko 2. Heikko- ja vahva-asteinen monikon illatiivi monitavuisilla vartaloilla (Internet-keskusteluja, https://korp.csc.fi)

\begin{tabular}{|l|r|r|l|r|r|l|r|r|}
\hline \multicolumn{3}{|c|}{$\begin{array}{c}\text {-kkA-loppuiset } \\
\text { kolmitavuiset }\end{array}$} & \multicolumn{3}{c|}{$\begin{array}{c}\text {-kkO-loppuiset } \\
\text { kolmitavuiset }\end{array}$} & \multicolumn{3}{c|}{-ttA-loppuiset } \\
\hline & kk & k & & kk & k & & tt & t \\
\hline haarukka & 1 & 42 & aallokko & 9 & 6 & kajuutta & 17 & 1 \\
\hline harakka & 0 & 60 & asteikko & 11 & 6 & komeetta & 23 & 3 \\
\hline kirsikka & 1 & 11 & evakko & 81 & 103 & navetta & 129 & 178 \\
\hline klinikka & 4 & 65 & femakko & 15 & 25 & planeetta & 337 & 30 \\
\hline kronikka & 0 & 13 & fyysikko & 5 & 24 & pohatta & 2 & 2 \\
\hline kännykkä & 38 & 1180 & kolikko & 21 & 83 & profeetta & 905 & 59 \\
\hline lusikka & 1 & 27 & kriitikko & 11 & 70 & valuutta & 546 & 33 \\
\hline
\end{tabular}

10 Haku tehty marraskuussa 2016. 


\begin{tabular}{|c|c|c|c|c|c|c|c|c|}
\hline majakka & 1 & 19 & kyynikko & 1 & 5 & & & \\
\hline mansikka & 2 & 116 & laatikko & 215 & 1615 & \multicolumn{3}{|l|}{-tti-loppuiset } \\
\hline mellakka & 4 & 481 & lammikko & 9 & 41 & & tt & $\mathbf{t}$ \\
\hline mustikka & 1 & 59 & lompakko & 28 & 63 & abortti & 904 & 12 \\
\hline myräkkä & 0 & 10 & lätäkkö & 10 & 70 & agentti & 43 & 1 \\
\hline patukka & 1 & 53 & maallikko & 24 & 114 & ammatti & 3469 & 114 \\
\hline penikka & 5 & 34 & maljakko & 8 & 84 & antibiootti & 228 & 4 \\
\hline persikka & 0 & 7 & metsikkö & 13 & 53 & automaatti & 500 & 11 \\
\hline piirakka & 3 & 89 & muusikko & 19 & 101 & boikotti & 59 & 0 \\
\hline porukka & 97 & 2594 & päällikkö & 7 & 46 & idiootti & 713 & 12 \\
\hline puolukka & 0 & 26 & otsikko & 151 & 3832 & marketti & 712 & 49 \\
\hline ratikka & 7 & 112 & portaikko & 28 & 1 & maistraatti & 53 & 1 \\
\hline silakka & 0 & 52 & ristikko & 8 & 42 & minuutti & 142 & 1 \\
\hline simpukka & 1 & 29 & sammakko & 5 & 99 & patrioottotti & 17 & 0 \\
\hline tekniikka & 22 & 528 & skeptikko & 48 & 95 & raketti & 408 & 16 \\
\hline tupakka & 7 & 49 & taulukko & 32 & 291 & robotti & 120 & 0 \\
\hline urakka & 8 & 203 & teknikko & 2 & 13 & salaatti & 511 & 9 \\
\hline ötökkä & 3 & 163 & yksikkö & 148 & 1243 & sateliitti & 46 & 5 \\
\hline \multirow[t]{2}{*}{ yhteensä } & 207 & 6022 & yhteensä & 909 & 8125 & sitaatti & 420 & 6 \\
\hline & $3,3 \%$ & $96,7 \%$ & & $10 \%$ & $90 \%$ & tabletti & 580 & 94 \\
\hline \multicolumn{3}{|c|}{-kkA-loppuiset monitavuiset } & \multicolumn{3}{|c|}{-kkO-loppuiset nelitavuiset } & tomaatti & 117 & 2 \\
\hline almanakka & 16 & 0 & allergikko & 11 & 0 & & 9042 & 337 \\
\hline dynamiikka & 1 & 0 & astmaatikko & 4 & 0 & & $96,4 \%$ & $3,6 \%$ \\
\hline patriarkka & 15 & 0 & dogmaatikko & 5 & 0 & & & \\
\hline \multirow[t]{7}{*}{ statistiikka } & 7 & 0 & fanaatikko & 111 & 13 & & & \\
\hline & & & poliitikko & $1595+^{*}$ & $303+$ & & & \\
\hline & & & \multicolumn{3}{|c|}{-kkO-loppuiset, 5 tavua } & & & \\
\hline & & & analyytikko & 9 & 4 & & & \\
\hline & & & anorektikko & 20 & 27 & & & \\
\hline & & & $\begin{array}{l}\text { matemaa- } \\
\text { tikko }\end{array}$ & 9 & 7 & & & \\
\hline & & & $\begin{array}{l}\text { systemaa- } \\
\text { tikko }\end{array}$ & 1 & 0 & & & \\
\hline
\end{tabular}

* Internet-keskusteluja-alakorpuksessa oli sekä muotoa politiik(k)oihin että poliitik(k)oihin useimmiten käytetty sanan poliitikko monikon illatiivin merkityksessä, minkä takia sekä vahva- että heikkovartaloisen monikon illatiivin edustus on jonkin verran suurempi, vaikka proportionaalisesti suhde jää samanlaiseksi. 
Tulokset ovat taulukossa 2 ja niistä ilmenee sama tendenssi kuin ISK:n mainitsema: heikkoasteisuus on yleinen kolmitavuisilla $k k A$-loppuisilla sanoilla samoin kuin kolmitavuisilla - $k k O$-loppuisilla sanoilla, vaikka niiden tapauksessa edustus ei ole niin ylivoimaisesti heikkoasteinen. Sen sijaan -tti-loppuisilla sanoilla on yleinen vahva-asteinen monikon illatiivi. Niissä ryhmissä, joissa on frekventissä käytössä vähemmän lekseemejä (pitemmät $-k k A$ - ja $-k k O$-loppuiset vartalot, - $t t A$-loppuiset vartalot), jotka esiintyvät aineistossa monikon illatiivissa harvoin, on vaikeaa tehdä koko ryhmälle päteviä yleistyksiä.

$-k k A$ - ja $-k k O$-loppuisten sanojen heikkoasteisilla monikon illatiiveilla voidaan ajatella olevan yhteinen skeema [ILL.PL/2tavua+kOihin]. Yleisempi skeema kuin [ILL. $\mathrm{PL} / 2$ tavua $+\mathrm{kOihin}$ ] olisi [ILL.PL/...hin], jonka alle kuuluvat myös vahva-asteiset illatiivimuodot kuten pankkeihin, aukkoihin, asuntoihin, tomaatteihin yms. Kolmitavuisille -kka ja - $k k O$ lopuville sanoille yhteinen skeema [ILL.PL/2tavua+kOihin] on konkreettisempi ja siten helposti käytettävissä. Ilmiö ei näytä ainakaan nykysuomessa ulottuvan muihin astevaihtelullisiin monitavuisiin vartaloihin, vaan ne esiintyvät vahvavartaloisina (kaupunkeihin, tomaatteihin), samalla tavalla kuten lyhyemmät (suukkoihin, sääntöihin) ja useimmiten myös pitemmät $-k k A$ ja $-k k O$ loppuiset vartalot (patriarkkoihin, fanaatikkoihin). Spesifimpi skeema voi siis olla "vahvempi" kuin yleisempi skeema. Käyttöpohjaisen lähestymistavan luonteeseen kuuluisi pikemminkin nähdä skeema [ILL.PL/2tavua+kOihin] primaarina resurssina, eikä olettaa ensin yleistä skeemaa tai sääntöä (esim. "monikon illatiivissa on aina vahva aste") ja sitten todeta ne poikkeukselliset tapaukset, joihin se ei päde.

Vartalo on syytä ottaa huomioon myös silloin, kun päätettä -Vn käytettäessä syntyy illatiivimuotoon pitkä vokaali. Päätettä - Vn käytettäessä pidennetään vartalon vokaali ja lisätään $n^{11}$. Pitkävokaalisuus yhdistää niitä muotoja, jotka on saatu aikaan päätteiden seen, -siin, - Vn ja -in avulla. Vokaalin pituus on joskus ratkaisevassakin roolissa, ja esimerkiksi muoto taloomme on sen ansiosta tunnistettavissa illatiiviksi.

Jos kuitenkin katsotaan, että vartalon muoto osallistuu jollakin tavalla illatiivin muodon ilmaisemiseen, seuraa kysymys, miten tämä osallistuminen on kuvattava. Tähän kiinnitetään huomiota seuraavassa luvussa. Kielen yksikköjen ja erityisesti dependenttien morfeemien analyysissä on tarpeellista muistaa, että niiden erottaminen kontekstista on abstrahointia niitä laajempien kokonaisuuksien - sananmuotojen - rakenteiden pohjalta (Langacker 2000, 46-47). Vartalo on kuitenkin muun morfeemin, illatiivissa olevan nominin fonologinen napa. On siis tarpeen kuvata myös sitä, miten vartalo ja pääte liittyvät toisiinsa. Tällöin on kyse syntagmaattisesta relaatiosta.

11 Toisin on esimerkiksi yksikön partitiivissa sauna-a tai kylä-ä, joissa pitkä vokaali muodostuu morfeemirajan yli vain silloin, kun vartalon loppuvokaali ja päätteen vokaali on sama (vrt. yksikön partitiiveihin talo- $a, k u l k u-a$ ). Tässä yhteydessä voidaan mainita, että vanhemmissa kieliopeissa puhutaan nimenomaan vokaalin pidennyksestä ja $n$ :n lisäämisestä (esim. Penttilä 1963, 191); merkintätapa - $V n$ on suhteellisen moderni ja perustuu olennaisesti sellaiseen suomen fonologian tulkintaan, jossa pitkät vokaalit (ja konsonantit) nähdään identiteettiryhmänä (ks. Karlsson 1982, 70-73). 


\subsection{Valenssisuhteet, autonomiset ja dependentit morfeemit}

Valenssisuhdetta edellytetään kognitiivisessa kieliopissa jokaisen syntagmaattisen yhdistelmän takana eli aina, kun yksiköt liitetään toisiinsa. Yksinkertaistaen perusoletus on se, että kahdella liitettävällä rakenteella pitää olla jotakin yhteistä, jotta yhdistäminen olisi mahdollista, eli jokin sellainen kohta, jonka kautta yhdistäminen onnistuu. Tätä kutsutaan elaboraatiopohjaksi (Langacker 1987, 277-282, 304; ks. myös Leino 1989, 178-182). Syntagmaattisten yhdistelmien kuvauksessa käytetään samoja yleisiä periaatteita sekä semanttisella että fonologisella puolella. Morfeemien yhdistelmässä on sitten kyse yhdistämisestä sekä semanttisella että fonologisella navalla, koska toisiinsa liittyvät symboliset yksiköt. Illatiivi on, kuten muutkin sijat, sekä semanttisesti että fonologisesti dependentti, siinä missä nominivartalo on autonominen (tällainen autonomisuuden ja dependenttiyden korrelaatio fonologisella ja semanttisella navalla mainitaan varsin vahvana tendenssinä, Langacker 1987, 336). Semanttisesti tämä dependenttiys on nähtävissä esimerkiksi siinä, että illatiivin avulla ilmaistaan suhdetta muuttujan ja kiintopisteen välillä (muuttuja siirtyy separaatiosta kiintopisteen inkluusioon), ja siinä, että olisi vaikeaa luonnehtia tätä suhdetta viittaamatta ollenkaan entiteetteihin, joiden välisestä suhteesta on kysymys. Toisaalta nominivartalon edustamaa merkitystä voi yleisesti luonnehtia ilman viittausta sijaan tai sijoihin, joiden kanssa se voi esiintyä. (Leino 1999, 82-83, 220-221.)

Fonologisesti on hyvinkin selvää, että kaikki affiksit ovat dependenttejä. Ne tarvitsevat omaan realisaatioonsa vartalon, johon liittyvät, mikä näkyy esim. vertailtaessa suomen illatiivin suffikseja - $V n$ ja -in, joiden fonologinen/foneettinen realisaatio ei ole ollenkaan ajateltavissa ilman vartaloa. Dependentti morfeemi on siis sellainen, joka on ikään kuin operaatio vartalolla (Langacker 1987, 336). Autonomisen ja dependentin ero perustuu ensinnäkin siihen, että dependentti osarakenne sisältää viittauksen toiseen osarakenteeseen (esim. suffiksi viittaa vartaloon), kun taas autonominen osarakenne ei tällaista viittausta olennaisessa määrin sisällä. Ero ei liity distribuutioon, eli kyse ei ole siitä, voiko kyseinen osarakenne esiintyä muissa konteksteissa ilman toista osarakennetta. Ero on asteittainen, ja usein voisi pikemminkin sanoa, että toinen osarakenne on enemmän dependentti ja toinen enemmän autonominen. Asymmetria suhteessa autonominen vs. dependentti on tyypillistä, mutta ei sääntönä. (Langacker 1987, 325, 328-348.)

Taivutuksen kuvauksessa korostuu usein konstruktiivinen puoli, jolloin puhutaan taivutustunnusten liittämisestä sanavartaloon (ISK $\$ 53$; Koivisto 2013, 73). Karlsson esittelee sijamuodon muodostamisen morfologisena operaationa, jossa perusmuotoon liitetään pääte. Operaatioon kuuluu usein suffiksin liittämisen ohella molempien liitettävien osien mukaistaminen oikean- tai vasemmanpuoleiseen kontekstiin sopivaksi. (Karlsson 1982, 24-27.) Toisaalta Langacker (2000, 46-47) esittää, että puhujan näkökulmasta primaari on pikemminkin sana (tai sananmuoto), jonka osat tunnistetaan abstrahoinnin kautta. Suomen morfologian kuvaukseen tuo jonkin verran uutta näkökulmaa oletus, että dependentin morfeemin osana pidetään tietoa skemaattisesta vartalosta (vrt. Langacker 1987, 337-338). Illatiivin tapauksessa suffiksit ovat muodossa ...han, ...hin, ...en, ...seen jne., jossa ... merkitsee mitä tahansa fonologista edustumaa ja on siten skemaattinen 
vartalo. Tämä skemaattinen vartalo toimii elaboraatiopohjana syntagmaattisessa sulautumassa vartalo + pääte (esim. yhdistelmässä talo- $+\ldots V n$, jossa talo- ja ... sulautuvat, eli skemaattinen vartalo ... tulee elaboroiduksi konkreettisen vartalon talo- avulla). Tätä skemaattista vartaloa voi kuitenkin usein luonnehtia joistakin osista spesifimmin, esim. ...a-han, ...i-hin, ...e-en, ...VV-seen. Kuten jo aikaisemmin oli esillä, myös pääte voi olla osittain skemaattinen $(-h V n,-V n)$, skemaattisen vartalon kanssa siis esimerkiksi $\ldots V-h V n$, $\ldots V-V n^{12}$. Koska illatiivin päätteet liittyvät aina tietyntyyppisiin vartaloihin, skemaattisen vartalon voi esittää vähän spesifimmässä muodossa kuin vain kolmena pisteenä.

Kun oletetaan illatiivin muodoksi pääte ja skemaattinen vartalo eikä vain pääte itsessään, on mahdollista ajatella, että vartalon fonologinen koostumus osallistuu illatiivin ilmaisemiseen. Ajatus sinänsä ei ole uusi: Anttila (1974) puhuu allomorfien semioottisesta funktiosta, jolla hän tarkoittaa sitä, että allomorfi omalla muodollaan viittaa itsensä ulkopuolelle ja kertoo jotakin vasemman- tai oikeanpuoleisesta kontekstista. Langackerin ja Anttilan käsitysten välillä voi nähdä kaksi eroa. Langackerin mukaan tällainen viittaus on osa dependenttiä rakennetta - skemaattinen vartalo on affiksin osa eikä siten viittaa osarakenteen ulkopuolelle. Anttilan $(1974,334)$ mukaan "allomorfit viittaavat rajojensa yli laajempiin kokonaisuuksiin, tavallisesti sanoihin". Toinen ero on siinä, että Langackerin mukaan tällainen viittaus on jokaisen dependentin rakenteen osa eli jokaiselle affiksille on ominaista skemaattinen vartalo, joka on sen dependentin luonteen ilmentymä. Anttilan semioottinen funktio liittyy allomorfeihin, jotka oman erilaisuuden ansiosta kertovat jotakin esiintymiskontekstistaan. (Langacker 1987, 306-308, 336-345; Anttila 1974, 333-335.) Langackerin mukaisessa käsityksessä toisistaan eroavat allomorfit kertovat vähän enemmän kontekstista (vrt. illatiivin pääteallomorfit ja niiden edellyttämä vartalon muoto edellä), kuin aina samassa muodossa esiintyvät dependentit morfeemit (esimerkiksi allatiivin pääte -lle, joka kuitenkin viittaa samalla tavalla vartaloon kuin illatiivin pääteallomorfit).

Samalla voidaan kiinnittää huomiota myös siihen, että yhdistelmässä nomini + sijapääte nominia edustaa vartalo (ISK $\$ 53$ ) ja termillä vartalo viitataan sellaiseen nominin fonologiseen edustumaan, joka edellyttää päätettä (esim. käte-, huonee-). Karlssonin (1982, 184-187) mukaan vapaa morfeemi ei esiinny tällöin syntagmaattisessa yhdistelmässä perusmuodossaan, vaan oikeapuoleinen konteksti edellyttää muutosta vapaan morfeemin muodossa. Onko siten myös vartalo dependentti, kun se edellyttää päätettä? Kyse on Langackerin $(1987,408)$ mukaan jostakin muusta. Dependentin ja autonomisen osarakenteen määritelmä ei perustu distribuutioon eli siihen, millaisissa ympäristöissä kyseinen osarakenne voi esiintyä, vaan dependentti rakenne sisältää viittauksen autonomiseen (esim. suffiksi sisältää viittauksen edeltävään osarakenteeseen). Dependentti rakenne siis edellyttää toista osarakennetta (kuten suffiksit - $h V n$,-seen), mutta sekä vartalo että pääte esiintyvät pakollisesti toisen osarakenteen kanssa. Langackerin (mp.) mukaan ero tällaisten riippuvuuksien välillä voi viime kädessä olla vain asteittainen, mutta ero

12 Reduplikatiivisille morfeemeille on tyypillistä juuri se, että skemaattinen vartalo on osittain spesifioitu, affiksi taas on osittain skemaattinen (Langacker 1987, 339). 
niiden välillä on kuitenkin tehtävä. Distributionaalinen riippuvuus tarkoittaa itse asiassa sitä, että päätteiden ja vartaloiden kaltaiset osarakenteet ovat aina abstrahoituja joistakin suuremmista kokonaisuuksista, ja konteksti, jossa ne esiintyvät, vaikuttaa niiden muotoon. Seuraavaksi kiinnitetään huomiota laajempiin kokonaisuuksiin, joissa vartaloon liittyy useampi dependentti morfeemi.

\subsection{Morfeemien hierarkia ja kielen yksiköt}

Illatiivin pääte esiintyy myös kompleksisemmissa syntagmaattisissa yhdistelmissä kuin vartalo + pääte. Kun otetaan huomioon selvästi morfologiset yhdistelmät (joiden tuloksena on sananmuoto), illatiivi esiintyy sellaisissa yhdistelmissä, joissa on vartalo, monikon tunnus ja sijapääte, jonka jälkeen voi olla possessiivisuffiksi ja sen jälkeen liitepartikkeli ${ }^{13}$. Kompleksisemmista yhdistelmistä voi analysoida myös niiden sisäistä hierarkiaa. Yleisesti ottaen kahden osarakenteen yhdistelmää muokataan liittämällä kolmas (Langacker 1987, 310-316). Monikollisten illatiivimuotojen hierarkiassa voi olettaa ensimmäiseksi askeleeksi vartalon ja monikon tunnuksen yhdistämisen, minkä jälkeen tällaiseen yhdistelmään liittyy sijapääte, ja näin muodostettuun yhdistelmään voi liittyä possessiivisuffiksi (vrt. kuva 2).

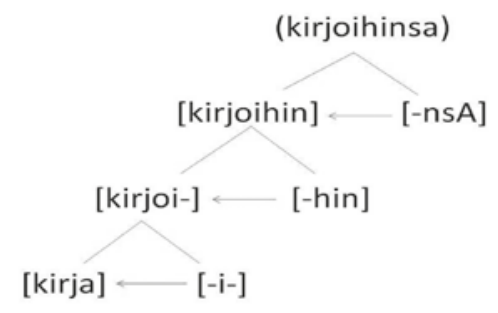

Kuva 2. Monikon, illatiivin ja possessiivisuffiksin hierarkia, fonologinen napa (ks. Langacker 1987, 313).

Kuvassa 2 hakasulkeilla osoitetaan, että muoto kirjoihin on siinä määrin frekventti ja tunnettu, ettei sitä välttämättä tarvitse muodostaa osista, vaikka sekin on tietenkin mahdollista. Monikon vartalo kirjoi- esiintyy muissakin monikon muodoissa ja voi olettaa, että puhujan ei tarvitse joka kerta käyttää sääntöä, jonka mukaan kaksitavuisten $a$-vartalojen loppu- $a$ muuttuu $o: k s i$, kun ensi tavun ensimmäinen vokaali ei ole pyöreä vokaali (vrt. ISK $₫ 80$; White 2001, 50-51). Puhujalla olisi siis vartalon ja monikon tunnuksen

13 Illatiivi esiintyy tietenkin myös väljemmissä, selvästi syntaktisissa yhdistelmissä, joista osaa voi varmasti pitää kieleen vakiintuneina yksikköinä, vrt. esim. [osallistua + NOM-ILL], [viitata + NOMILL], [mennä pieleen], [mennä metsään]. 
yhdistelmä kirjoi- valmiina käytettävissä. Sen sijaan muotoa kirjoihinsa ei pidetä tässä kuviossa yksikkönä, eli oletetaan pikemminkin, että puhujalla on mahdollisuus koostaa se yksiköistä [kirjoihin] ja [-nsA]. Samalla on muistettava, että yksikön status on asteittainen ominaisuus. Nuolet osoittavat, kumpi konstituenteista on dependentti (suunta on dependentista autonomiseen). (Ks. Langacker 1987, 312-313; Leino 1989, 179.)

Fonologisesti tämäntyyppisestä konstituenttien hierarkiasta kertoo se, että illatiivin päätteen vokaali määräytyy monikon tunnuksen vokaalin mukaan, kuten myös se, että päätteen loppu- $n$ katoaa possessiivisuffiksin edeltä. Semanttisestikin tuntuu luontevalta ajatella konstituenttien hierarkiaa, jossa ensin muodostetaan monikko. Näin saadaan replikoitu joukko niitä entiteettejä, joita vartalo profiloi (Langacker 1991, 77-90). Sitten tämä monikollinen entiteetti otetaan illatiivin profiloituun suhteeseen sen kiintopisteeksi. Tämä tuntuu luontevammalta kuin esimerkiksi ajatus, että toisiinsa liittyvät monikko ja illatiivi, joiden yhdistelmä sitten yhdistetään nominivartalon kanssa. Semanttisellakin puolella olisi kaikissa tapauksissa sama osarakenne autonominen vs. dependentti, kuten on merkitty kuvaan 2, vaikka tämä kuvio kuvaa fonologista napaa.

Konstituenttien hierarkialla ei tarvitse kuitenkaan olla kauas ulottuvia vaikutuksia. Konstituentti on olemukseltaan jotain muuta kuin kielen yksikkö (Langacker 1987, 313-316). Yksikkö voi olla rakenteeltaan kompleksinen eli jaettavissa pienempiin osiin. Yksikkö voi siis hyvinkin olla analysoitavissa ja sen osat tunnistettavissa (tai joinain hetkinä tunnistettuja). Näin voidaan olettaa, että yksikön status on monikon illatiivin skemaattisilla muodoilla [...ihin], [...iin], [...isiin]. Edellä mainitun kaltaiset, osaltaan skemaattiset yksiköt syntyvät abstrahoimalla erilaisten toteutumien pohjalta (esim. kirjoihin, maihin, otsikoihin, juttuihin, saunoihin yms. > ...ihin) eli silloin, kun sama loppusekvenssi (ja tässä myös kahden morfeemin yhdistelmä) toistuu monissa tapauksissa. Langacker (1987, 314-315) ehdottaa muun muassa englannin kielen skeemaa [STEM-er-s], joka on abstrahoitu toteutumista kuten drivers, workers, computers. ${ }^{14}$

Eron tekeminen konstituenttien ja yksikköjen välillä osoittautuu siis hyödylliseksi. Näin voi ottaa huomioon sen, että morfeemien jonoja -i-hin, -i-in, -i-siin on toisaalta parempi pitää yhtenä kokonaisuutena. Karlssonin (1982, 25, 190) mukaan monikon genetiivin, partitiivin ja illatiivin kuvaus helpottuu, jos monikon tunnus ja sijan pääte sijoitetaan samanaikaisesti. Hän merkitseekin monikon illatiivin päätteet muodoissa isiin, ihin, iin (mt. 292-293). Samalla otetaan huomioon myös se, että koko taivutussysteemin kuvauksen kannalta tuntuu hyödylliseltä olettaa välittömiksi konstituenteiksi vartalo ja

14 Tiina Onikki-Rantajääskö analysoi paikallissijaisten olotilanilmausten monikon tunnuksen ja sijapäätteen (myös possessiivisuffiksin ja monikon tunnusta edeltävien johtimien) kiteytyneisyyttä: Eri ilmaukset eroavat siinä, missä määrin sijapäätettä edeltävä $i$ on mahdollista tulkita monikon $i$ :ksi. Niitä ilmaisuja, joissa monikon tunnus ei näytä olevan semanttisesti motivoitunut, on mahdollista selittää analogisina. Olotilanilmausten morfologisena skeemana on näin esim. [VARTALO + i + SISÄSIJA]. (Onikki-Rantajääskö 2012, 61-69, 43-54.) Tässä artikkelissa on tarkoitus korostaa etenkin sitä, että toistuva loppusekvenssi on mahdollista tulkita kokonaisuudeksi myös silloin, kun se on jaettavissa osiin, jotka ovat selviä yksikköjä sinänsä. Voi myös katsoa, että kiteytyminen on tätä seuraava askel, jolloin loppusekvenssin osien motivaatio ainakin osittain katoaa. 
monikon tunnus, joiden yhdistelmään liittyy sijapääte (esim. puhutaan monikkovartalosta, joka esiintyy eri monikkomuodoissa).

\section{Taivutustyypit taivutusmorfologian kuvauksessa}

Taivutustyyppi on käsite, jonka avulla voi hahmottaa paradigmaattisia kytköksiä eri sijamuotojen välillä, ja lisäksi on se väline, jonka kautta lähestytään taivutussysteemiä kielen opetuksessa ja annetaan taivutusohjeita sanakirjoissa. Taivutustyypillä tarkoitetaan yhdenmukaisesti taipuvien sanojen ryhmää tai myös niiden taivutusmallia (ISK $₫ 63$; Koivisto 2013, 75-77). Sanojen jakamisessa taivutustyyppeihin ovat ratkaisevia sanan hahmo (tavuluku, vokaalivartalon loppu), vartalonvaihtelut ja taivutuspäätteistö (ISK $\$ 147$; Koivisto 2013,75 ). Taivutustyyppien luku vaihtelee ensinnäkin sen mukaan, kuinka hienoja eroja sanojen taivutuksessa otetaan huomioon (vrt. Karlsson 1982, 202-203). Paunonen (1976, 87-90) on kiinnittänyt huomiota siihen, että taivutustyypit usein limittyvät - joidenkin muotojen osalta niitä ei voi erottaa toisistaan (esim. hammas : hammasta, kannas : kannasta, kulmaus : kulmausta ja kulmaus : kulmauksia, rakkaus : rakkauksia), toisaalla on eroja, jotka ovat taivutustyypin erottamisen perusteena (esim. hammas : hampaan vs. kannas: kannaksen ja kulmaus : kulmauksen vs. rakkaus : rakkauden).

Taivutustyyppien järjestelmä ei ole vain luokittelemisen väline ja käytännöllinen tapa oppia tai kuvailla taivutusta. Taivutustyyppien järjestelmä perustuu muotojen välisiin suhteisiin, ja muodot määräytyvät sekä taivutustyyppien keskinäisten että paradigman sisäisten yhteyksien perusteella (Paunonen 1976, 101). Toiseksi mainittu vaikutus ilmenee Paunosen (mp.) mukaan monikon illatiivissa (vrt. myös Itkonen 1959; Karlsson 1982, 38-40), eli monikon illatiivin pääteallomorfin (-in, -hin, -siin) valinta ohjautuu muiden paradigmamuotojen mukaan. Yksi tapa kuvailla tätä on jäsentää monikon genetiivin, partitiivin ja illatiivin pääteallomorfit kolmeen sarjaan 1) -ien : -iA : -iin, 2) -iden/-itten : -itA : -isiin ja 3)-\{ij\}en : -jA : -ihin (vrt. esim. ihanien : ihania : ihaniin, tärkeiden : tärkeitä : tärkeisiin ja asuntojen : asuntoja: asuntoihin tai apteekkien : apteekkeja: apteekkeihin), mutta järjestymisen mahdollisuuksia olisi toki muitakin. Monitavuisilla vartaloilla esiintyy mainituissa muodoissa usein myös rinnakkaisia muotoja, jotka voidaan nähdä erisuuntaisten vaikutusten tuloksina, esim. paperien $\sim$ papereiden/papereitten, omenia omenoita, otsikkoja otsikoita, otsikkoihin otsikoihin (vrt. ISK \$90-94).

Kysymys onkin, miten tämän taivutussysteemin ulottuvuuden voisi kytkeä aiemmin ehdotettuihin kuvaustapoihin ja oletukseen, että taivutussysteemi ei ole mitään muuta kuin erilaisten ja erilaisessa määrin skemaattisten yksikköjen jäsentynyt varasto. Onko taivutustyyppi myös skeema ja voiko taivutustyyppejä pitää kielen yksikköinä?

Kognitiivisen kieliopin teoreettiseen taustaan nojautuvassa taivutustyyppien käsittelyssä tulevat keskeisiksi käsitteiksi skeema (ja yleistys skeemoihin), kategorisointi (skeeman tai prototyypin tai molemman prinsiipin mukainen) ja ns. käyttöpohjainen lähestymistapa. Samalla tavalla kuin skeemat [ILL.PL/...iin], [ILL.PL/...isiin] tai [ILL.PL/...ihin] ovat yleistyksiä erilaisten monikon illatiivien pohjalta, on yleistys skeemaan mahdollinen 
myös samoin taipuvien sanojen pohjalta. Edellytyksenä on sellaisten toteutumien olemassaolo, jotka ovat fonologisesti samankaltaisia joissakin kohdissa (muodot ovat samanlaisia vain osittain, muut ominaisuudet, esim. vartalon fonologinen rakenne, tavuluku ym., jätetään huomiotta). Käyttöpohjaisesta lähestymistavasta puhutaan muun muassa sen takia, että yleistys skeemaan on aina sellainen, jonka olemassa olevat toteutumat sallivat, eli ei oleteta abstraktimpia skeemoja tai sääntöjä kuin millaisiin on kielessä olemassa mahdollisuuksia. (Langacker 2000, 2-3.)

Erilaiset taivutustyypin kaltaiset skeemat saattavat olla eri määrin skemaattisia ja myös päällekkäisiä (eli limittäisiä, Paunonen 1976). Esimerkiksi monikon muotojen ajatuksien : ajatuksia: ajatuksiin : jne., salaisuuksia : salaisuuksien : salaisuuksiin : jne. skeema pätee monikkotaivutuksessa, ja toisaalta samojen sanojen yksikkömuodot edustavat kahta erilaista skeemaa.

Paradigmaattiset yhteydet ovat ratkaisevia monikon illatiivin päätteiden -siin ja -hin distribuutiossa (vrt. esim. huoneisiin : huoneita, mutta hotelleihin : hotelleja; ISK \$ 94). Esitetyssä kuvauksessa on täten taivutustyyppi-skeeman [[ILL.PL/...isiin] : [PART.PL/...itA] : [GEN.PL/...iden]] olemassaolo ratkaiseva sellaisten muotojen sanktioinnissa kuin huoneisiin, tärkeisiin, nopeisiin. Mainitun taivutustyyppi-skeeman takia nämä muodot tuntuvat luonnollisemmilta kuin muodot huoneihin, tärkeihin, nopeihin ${ }^{15}$. Mahdollisista vaihtoehdoista [ILL.PL/...isiin] ja [ILL.PL/...ihin] on niiden muotojen sanktioinnissa ensimmäiseksi mainitulla skeemalla etuoikeus mainitun taivutustyyppi-skeeman olemassaolon takia.

\section{Yhteenvetoa}

On ilmeistä, että esitetty lähestymistapa, jonka teoreettinen tausta ja lähtökohta on Langackerin kognitiivinen kielioppi, johtaa osaltaan sellaisiin näkökulmiin ja ratkaisuihin, jotka eivät ole suomen morfologian kuvauksessa kovin yllättäviä. Tällaisiin näkökulmiin kuuluu esimerkiksi käyttöpohjainen lähestymistapa tai kategorisointi konventionaalistuneiden skeemojen avulla, mikä vertautuu analogiseen muodostamiseen ja yhdenmukaistavan systeemin dynamiikkaan (vrt. Paunonen 1976). Yksi tässä artikkelissa esitetyn teoreettisen taustan tärkeistä ominaisuuksista on ilmiöiden kuvaaminen skalaarisina eikä jyrkkinä joko/tai-vaihtoehtoina (vrt. myös Langacker 1987, 28-30). Tässä artikkelissa on puhuttu vastaavasti esimerkiksi skemaattisuuden tasosta sekä prototyyppisyyden tai konventionaalisuuden asteesta. Morfologian kuvauksessa näyttää olevan tärkeä oletus, että kielen yksiköt voivat olla spesifisiä (esim. konkreettisia taivutusmuotoja) tai eri määrin skemaattisia (skeemoja). Taivutuksen systemaattisuus selittynee näiden varastoitujen ja konventionaalistuneiden skeemojen olemassaololla ja niiden välisillä suhteilla.

15 Virkkala $(2013,81)$ pitää kuitenkin vahvempana tendenssina ohut- ja tärkeä-tyyppisten nominien mukautumista supistumanominien taivutukseen, joten paradigman sisäinen vaikutus on toissijainen. 
Skeemoihin, joilla on yksikön status, voidaan lukea myös perinteisesti taivutustyypeiksi kutsutut skeemat.

Teoreettisista edellytyksistä seuraa myös se, että yhteen ja samaan muotoon voi viedä useampi polku. Taivutusmuoto voi olla jossain määrin valmiina käytettävä yksikkö, ja samalla se voi olla jonkin skeeman tai myös eri skeemojen sanktioima toteutuma. Esimerkiksi monikon illatiivi huoneisiin voi olla jossain määrin yksikkö itsessään, mutta samalla se on skeeman [ILL.PL/...isiin] toteutuma, ja omalta osaltaan myös skeeman [[GEN.PL/...iden] : [PART.PL/...itA] : [ILL.PL/...isiin]] toteutuma. Tätä voidaan verrata Paunosen (1976, 102-104) esittämään kuvaukseen, jossa sananmuodon vartalo ja pääte viittaavat abstrakteihin suhteisiin, joiden varassa taivutusjärjestelmä on muotoutunut, ja sananmuoto on näin kahden suhdejärjestelmän leikkauskohdassa. Taivutussysteemissä on yleensä myös runsaasti esimerkkejä siitä, että tällaiset mahdolliset polut eivät vie aina samaan muotoon: esimerkiksi toinen skeema motivoi muodot sellaisten/tulostinten, toinen taas muodot sellaisien/tulostimien. Näistä muodoista on yleensä jompikumpi yleisempi, mutta toisellakin skeemalla on oma paikkansa taivutussysteemissä ja se tarjoaa mahdollisuuden kategorisoida konkreettiset muodot suhteessa siihen. Kun taivutussysteemiä katsotaan erilaisten skeemojen varastona, on sille ominaista resurssien osittainen päällekkäisyys.

Morfologia on muodon ja merkityksen risteys, ja tuntuu luontevalta kuvata sitä niin, että samaa teoreettista taustaa on sovellettu sekä muodon että merkityksen kuvaukseen. Muodon tai merkityksen kuvaukseen voi toki liittyä myös jotain sellaista, mille toisen kuvauksessa ei löytyisi tarvetta, mutta näyttää silti oikeutetulta olettaa, että esimerkiksi kategorisointi tai yleistäminen skeemoihin toimii molemmissa tapauksissa samojen yleisten periaatteiden mukaisesti. Illatiivin ominaisuuksiin kuuluu olennaisesti sekä polyseemisyys että allomorfia. Näin ollen illatiivin morfeemin merkitys samoin kuin sen muoto on yleistys. Tätä morfeemia ei voi luonnehtia laatimalla muodon tai merkityksen ominaisuuksien listaa, vaan kuvauksessa täytyy kuvata sen kaikkia mahdollisia toteutumia eri skemaattisuuden tasoilla.

Kognitiivisen kieliopin tarjoama teoreettinen tausta voi myös olla hyvänä tukena käytännönläheisempiin sovelluksiin. Taivutussysteemin oppimisprosessissa ja opetuksessa ovat yleisesti keskeisessä asemassa sellaiset skeemat tai säännöt, jotka ovat sopivassa määrin skemaattisia. Skeemoina voivat toimia mainituista esimerkiksi sellaiset skeemat kuin [ILL.SG/...seen], [ILL.PL./...isiin], taivutustyypin tapainen skeema [GEN.PL/...iden] : [PART.PL/...itA] : [ILL.PL/...isiin] tai vaikkapa [ILL.PL/2tavua+kOihin] yms. Myös skeemojen päällekkäisyys itsessään on hyödyllistä oppimisprosessissa. Kognitiivisessa kieliopissa korostetaan spesifimpien skeemojen olennaisuutta eli tavallaan hyväksytään, että pyrkimisestä yleisiin skeemoihin ja sääntöihin, jotka kattaisivat mahdollisimman suuren alueen ja mahdollisimman paljon esimerkkejä, ei tarvitse aina olla sellaista hyötyä kuin konkreettisemmista skeemoista.

Lopuksi täytyy todeta, ettei taivutussysteemi muodosta kognitiivisen kieliopin kuvauksessa erillistä kieliopin lohkoa. Eri asteen yleiset skeemat, jotka kattavat eri määrin isoja 
alueita, eivät ole mitenkään tyypillisiä vain taivutussysteemille. Yleensä taivutussysteemin kuvaukseen halutaan etenkin sellaisia sääntöjä, jotka ovat aika yleisiä eli pätevät suuriin nominijoukkoihin. Yleisemmät skeemat kuten ILL.SG/... tai ILL.PL/... ovat yleistyksiä kaikista illatiivissa taipuvista nomineista, mutta taivutussysteemissäkin on spesifimpiä skeemoja ja idiosynkraattisuutta; esimerkiksi skeema ILL.PL/2tavua+kOihin on todettu sellaiseksi. Taivutussysteemin kuvauksen yleiset periaatteet eivät poikkea muiden kielen konventionaalisten yksikköjen kuvauksesta.

\section{Lähteet}

Anttila, Raimo 1974: Allomorfien semiotiikkaa. Virittäjä, 126-133.

ISK = Hakulinen, Auli - Vilkuna, Maria - Korhonen, Riitta - Koivisto, Vesa - Heinonen, Tarja RiItta - Alho, Irja 2004: Iso suomen kielioppi. Suomalaisen Kirjallisuuden Seura, Helsinki.

Hebedová, Petra 2016: Estonský a finský illativ v pohledu kognitivní gramatiky. Filozofická fakulta, Masarykova univerzita, Brno.

ITKONEN, Terho 1957: Mellakoihin vai mellakkoihin? Yleiskielemme eräiden taivutushorjuvuuksien taustaa. Virittäjä, 259-286.

1959: -siin vai -hin monikon illatiivissa? Pertti Virtaranta, Terho Itkonen ja PaAvo PulkKINEN (toim.): Verba docent: juhlakirja Lauri Hakulisen 6o-vuotispäiväksi 6. 10. 1959, 372-388. Suomalaisen Kirjallisuuden Seura, Helsinki.

1976: Syntaktisten vaikutusyhteyksien luonteesta. Virittäjä, 52-81.

Janda, Laura A. 1993 [2013]: A Geography of Case Semantics: the Czech Dative and the Russian Instrumental. Mouton de Gruyter, Berlin - New York.

KARLSSON, Fred 1982: Suomen kielen äänne- ja muotorakenne. WSOY, Porvoo - Helsinki - Juva.

KoIvisto, Vesa 2013: Suomen sanojen rakenne. Suomalaisen Kirjallisuuden Seura, Helsinki.

LAAKSONEN, KAINO - Lieko, ANNELI 1998: Suomen kielen äänne- ja muoto-oppi. Finn Lectura, Loimaa.

LANGACKer, Ronald W. 1987: Foundations of cognitive grammar I. Theoretical prerequisites. Stanford University Press, Stanford, California.

1991: Foundations of cognitive grammar II. Descriptive application. Stanford University Press, Stanford, California.

2000: A Dynamic Usage-based Model. Michael Barlow ja Suzanne Kemmer (toim.): UsageBased Models of Language, 1-63. Stanford, Calif.: CSLI Publications.

Leino, Pentti 1989: Paikallissijat ja suhdesääntö - kognitiivisen kieliopin näkökulma. Virittäjä, 161219.

1993 [1999]: Polysemia - kielen moniselitteisyys. Kieli 7. Helsingin yliopiston suomen kielen laitos, Helsinki.

Leino, Pentti - Helasvuo, Marja-Lisssa - Lauerma, Petri - Nikanne, Urpo - Onnikki, Tiina 1990: Suomen kielen paikallissijat konseptuaalisessa semantiikassa. Kieli 5. Helsingin yliopiston suomen kielen laitos, Helsinki.

Mä̈̈тtё, URho 1998: Suomalaisesta kenttämorfologiasta. Klaus LaAlo (toim.): Kirjoituksia muoto- ja merkitysopista, 1-24. Tampereen yliopisto, Tampere.

Onikki, TiInA 1994: Skeema merkitysrakenteen ja taustatiedon kuvauksessa. Pentti Leino ja TiInA ONIKKI (toim.): Suomen kielen kognitiivista kielioppia 2. Kieli 8. Helsingin yliopiston suomen kielen laitos, Helsinki.

Onıkкi-RantajäÄsкö, Tiına 2001 [2012]: Sarjoja. Nykysuomen paikallissijaiset olotilanilmaukset kielen analogisuuden ilmentäjinä. Suomalaisen Kirjallisuuden Seura, Helsinki.

Paunonen, Heikki 1976: Allomorfien dynamiikkaa. Virittäjä, 82-107. 
Penttilä, Aarni 1963: Suomen kielioppi. Toinen, tarkistettu teos. WSOY, Porvoo - Helsinki.

Rapola, MARTti 1965: Suomen kirjakielen historia pääpiirteittäin I. Vanhan kirjasuomen kirjoitus- ja äänneasun kehitys. Suomalaisen Kirjallisuuden Seura, Helsinki.

UUsitalo, LAURA 1996: Illatiivin polysemiaa kognitiivisen kieliopin näkökulmasta. Pro gradu -tutkielma. Helsingin yliopisto, Helsinki.

VAINIK, ENE 1995: Eesti keele väliskohakäänete semantika kognitiivse grammatika vaatenurgast. Eesti Teaduste Akadeemia - Eesti Keele Instituut, Tallinn.

Virkkala, Marke 2013: Monikon illatiivin rinnakkaismuotoisen hin-päätteen esiintyminen ja käyttö suomen kielessä. Pro gradu -tutkielma. Tampereen yliopisto.

White, LeILA 2001: Suomen kielioppia ulkomaalaisille. Finn Lectura, Helsinki.

\section{Petra HeBedová: Finnish illative and nominal inflection from the perspective of cognitive grammar}

Cognitive grammar framework has been widely reflected in descriptions of Finnish, including descriptions of its nominal inflection (e.g. Leino 1999, Onikki-Rantajääskö 2001). This paper focuses on some traditional morphological topics that are related to nominal inflection. It mainly looks at allomorphy, the interaction between the nominal stem and case ending, and declensional types. In this paper, the allomorphs of the illative case primarily serve as examples through which I try to present the possible application of cognitive grammar based on Langacker $(1987,1991,2000)$.

Langacker's $(1987,66-76,371-408 ; 2000,4-5)$ conception of categorisation and the concept of a schematic network are utilised for the description of allomorphy. This paper argues that several categorising relationships can be detected among the allomorphs of the illative case. There are six patterns for forming the illative, which can be considered to be schemas in cognitive grammar framework, for example in the illative singular [ILL.SG/...Vn], [ILL.SG/...hVn], [ILL.SG/...seen] and in the plural [ILL. PL/...in], [ILL.PL/...hin], [ILL.PL/...siin]. Apart from these schematisations, there is also one uniting all plural schemas stating that the vowel in the plural illative ending is i reduplicating the ending vowel of the plural stem. These plural allomorphs can also be considered to be extensions of the respective singular variant (for example ILL.SG/... seen ---> ILL.PL/...siin). The possibility of certain departures from the typical use of the aforementioned schemas (such as the use of the illative ending $-h V n$ by loans as in ateljee : ateljeehen) is explained by referring to the concept of partial sanction.

The interaction between the nominal stem and the case ending, which is a crucial topic in the description of Finnish inflectional morphology, is described using Langacker's conception of valence relations. The illative ending as a dependent morpheme makes reference to a schematic stem. The schematic stem (eg. '...' in ....seen) serves as an elaboration site in the stem-ending valence relation, being elaborated by a concrete nominal stem (e.g. huoneeseen). The fact that the nominal stem also often has a special form (referred to in Finnish as vartalo, in contrast to the nominative singular form) when it is part of such a construction, is considered, in a slightly different way, to be a distributional fact rather than a characteristic of the stem (according to Langacker 1987, 408). For larger constructions consisting of a plural ending and a possessive suffix in addition, this study also tackles the analysis of the hierarchy of constituents.

The description of the distribution of the plural illative endings (-hin vs. -siin) necessitates the notion of a declensional type. This notion is defined in reference to the concept of categorisation and in terms of a usage-based approach. The declensional type is considered to be a certain type of schema. 
It is also suggested that illative plural forms of trisyllabic nouns that end in $-k k a$ or $-k k O$ (e.g. mansikka 'strawberry', laatikko 'box', $y k s i k k o ̈$ 'unit'), which, unlike all other illative forms, exhibit the weak stem variant (e.g. mansikoihin, laatikoihin, yksiköihin), can be explained as examples of a local schema. Such a local schema is cognitively more salient than abstract schematic representations of the nominal stem in the illative, which would subsume all illative forms.

This study concludes with the argument that a description of Finnish inflection in terms of cognitive grammar partly leads to reasoning and solutions that have already been suggested in earlier descriptions of Finnish morphology (e.g. Itkonen 1959, Anttila 1974, Paunonen 1976). In some respects, such a description opens the possibility to slightly reconsider the approach to the topic.

\author{
Petra Hebedová \\ petrahebedova@phil.muni.cz \\ Masarykova univerzita \\ Filozofická fakulta \\ Ústav jazykovědy a baltistiky \\ Arna Nováka 1 \\ 60200 Brno, Tšekki
}

